\title{
(JIPD)
}

\author{
Jurnal Inovasi Pendidikan Dasar
}

Vol. 4, No. 1, Bulan Januari Tahun 2020, Hal. 62-70

E-ISSN: 2598-408X, P-ISSN: 2541-0202

http://unikastpaulus.ac.id/jurnal/index.php/jipd

\section{MELESTARIKAN KEARIFAN LOKAL DAERAH MANGGARAI MELALUI KEGIATAN MENDONGENG PADA ANAK SEKAMI USIA SD DI PAROKI SANTU NIKOLAUS KELURAHAN GOLO DUKAL}

\author{
${ }^{1}$ Fransiska Jaiman Madu, ${ }^{2}$ Mariana Jediut $\&{ }^{3}$ Maria Rahayu Anwar \\ ${ }^{1,2}$ PGSD UNIKA Santu Paulus Ruteng dan ${ }^{3}$ PBSI UNIKA Santu Paulus Ruteng \\ Jln Jend. Ahmad Yani No 10 Ruteng-Flores 86508 \\ Email: fransiskamadumgr@gmail.com
}

Diterima: 11 Januari 2020 , Direvisi: 15 Januari 2020, Diterbitkan: 31 Januari 2020

\begin{abstract}
Storytelling is a form of oral tradition as a means of communication and recording the events of life or human civilization of the past. Fairy tales are one of the places to preserve local wisdom. As for the fairy tale here is the fairy tale of the Manggarai area. Manggarai fairy tales were chosen with the aim of introducing various local wisdoms contained in these tales. this activity aims to; 1) introducing various local wisdoms in the Manggarai area to children of primary school age; 2) growing love for various local wisdoms in the Manggarai area; 3) grow and develop children's mental and ability to speak in frontother friends.in its implementation, this activity goes through several stages namely; 1) preparation stage which includes coordination of the service team, contacting partners, determining the schedule of activities, and procuring Manggarai folklore books; 2) the stage of implementation of activities which includes mentoring and training fordevelop the ability of children SEKAMI in knowing tales and storytelling.this activity aims to improve the ability of children SEKAMI in knowing more stories and good ways of storytelling; 3) the final stage includes storytelling and evaluation activities related to the effectiveness of service activities. this activity went well and the objectives of the activity were achieved.
\end{abstract}

Keyword: storytelling

\begin{abstract}
Abstrak: Mendongeng merupakan salah satu bentuk tradisi lisan sebagai sarana komunikasi dan merekam peristiwa kehidupan atau peradaban manusia masa lampau. Dongeng menjadi salah satu wadah untuk melestarikan kearifan lokal. Adapun dongeng yang dimaksud di sini adalah dongeng daerah Manggarai. Dongeng Manggarai dipilih dengan tujuan untuk memperkenalkan berbagai kearifan lokal yang terkandung dalam dongeng-dongeng tersebut. Kegiatan ini bertujuan untuk; 1) memperkenalkan berbagai kearifan lokal daerah Manggarai kepada anak-anak usia sekolah dasar; 2) menumbuhkan rasa cinta pada berbagai kearifan lokal daerah Manggarai; 3) menumbuhkan dan mengembangkan mental dan kemampuan anak-anak untuk berbicara di depan teman-teman lainnya. Dalam pelaksanaanya, kegiatan ini melewati beberapa tahap yakni ; 1) tahap persiapan yang meliputi koordinasi tim pengabdian, menghubungi mitra, penentuan jadwal kegiatan, dan pengadaan buku cerita rakyat Manggarai; 2) tahap pelaksanaan kegiatan yang meliputi pendampingan dan pelatihan untuk mengembangkan kemampuan anak-anak SEKAMI dalam mengenal dongeng dan mendongeng. Kegiatan ini bertujuan untuk meningkatkan kemampuan anak-anak SEKAMI dalam mengenal lebih banyak dongeng dan cara mendongeng yang baik; 3) tahap akhir meliputi kegiatan lomba mendongeng dan evaluasi terkait keefektifan kegiatan pengabdian. Kegiatan ini berjalan dengan baik dan tujuan kegiatan pun tercapai.
\end{abstract}

Kata Kunci : Mendongeng

\section{PENDAHULUAN}

Kearifan lokal merupakan bagian dari budaya suatu masyarakat yang tidak dapat dipisahkan dari bahasa masyarakat itu sendiri. Kearifan lokal (local wisdom) biasanya diwariskan secara turun temurun dari satu generasi ke generasi melalui cerita dari mulut ke 
mulut (Wikipedia). Kearifan lokal adalah identitas atau kepribadian budaya sebuah bangsa yang menyebabkan bangsa tersebut mampu menyerap bahkan menyerap kebudayaan yang berasal dari luar/bangsa lain menjadi watak dan kemampuan sendiri (Wibowo, 2015:17).

Berdasarkan beberapa pendapat tersebut dapat dikatakan bahwa kearifan lokal merupakan budaya atau adat yang dibentuk oleh kebiasaankebiasaan suatu kelompok masyarakat tertentu. Kebiasaan-kebiasaan tersebut mencakup sikap, perilaku, dan tutur kata. Oleh karena itu, kearifan lokal setiap daerah berbeda-beda karena kebiasaan-kebiasaan yang dibentuk dalam setiap kelompok masyarakat berbeda.

Kearifan lokal setiap daerah tentunya memiliki nilai yang baik dan bijaksana yang wajib diikuti oleh masyarakatnya karena kearifan lokal merupakan produk budaya masa lalu atau gambaran kehidupan masa lalu yang secara terus-menerus wajib dijadikan sebagai pegangan hidup.

Dalam kehidupan sehari-hari, kearifan lokal hendaknya menjadi pegangan utama baik dalam bersikap, beraktivitas, dan bertutur kata. Berikut merupakan fungsi kearifan lokal yang dikemukakan Ayat (1986:40-41) yakni :

a. Sebagai filter dan pengendali terhadap budaya luar.

b. Mengakomodasi unsur-unsur budaya luar.

c. Mengintegrasikan unsur budaya luar ke dalam budaya asli.

d. Memberi arah kepada perkembangan budaya.

Melihat fungsinya, kearifan lokal tentunya patut dijaga, dilestarikan, dan dijadikan pegangan dalam kehidupan masyarakatnya sehari-hari. Pelestarian kearifan lokal di setiap daerah dapat dilakukan dengan cara yang berbeda-beda seperti melalui cerita rakyat atau dongeng, peribahasa, lagu, tarian rakyat, ritus adat, dan permainan rakyat. Kearifan lokal sebagai suatu pengetahuan yang ditemukan oleh masyarakat lokal tertentu melalui kumpulan pengalaman dalam mencoba dan diintegrasikan dengan pemahaman terhadap budaya dan keadaan alam suatu tempat.

Seperti yang telah disebutkan sebelumnya bahwa dongeng merupakan salah satu media pelestarian kearifan lokal. Melalui dongeng, masyarakan zaman sekarang dapat memahami dan mengetahui berbagai macam kearifan lokal yang termuat di dalamnya baik secara implisit maupun eksplisit. Oleh karena itu, dongeng perlu dipelajari sejak dini pada anak- anak usia sekolah dasar. Melalui mendongeng, anak-anak akan mudah mempelajari berbagai kearifan lokal daerahnya. Hal ini sejalan dengan pernyataan lisan Soeharta (Senin, 13/11/2017) saat hadir dalam kegiatan lomba dongeng tingkat SD se-Kecamatan Cipocok Kota Serang yakni:

"Dongeng bisa membuat anak mengenal kearifan lokal, pesanpesan moral, nilai sejarah dari dongeng yang dibacakan. Mendongeng merupakan bentuk tradisi yang telah dipraktikkan selama ribuan tahun. Narasi dalam dongeng telah diwariskan dari generasi ke generasi melalui cerita rakyat, dan sekarang bagaimana anak-anak bisa mendongeng sesuai dengan kearifan lokal di masyarakat Banten."

Lebih lanjut, Soeharta (Senin, 13/11/2017) menyatakan

bahwa,

"Lomba dongeng merupakan bagian dari upaya untuk menanamkan pendidikan moral dan akhlak kepada anak. Mendongeng juga sarana untuk mewariskan nilai-nilai budaya dan sejarah. Melalui dongeng, anak-anak diberikan pemahaman tentang budaya, etika, dan norma."

Selanjutnya seorang psikolog ternama yaitu Monica Sulistiawati menyampaikan beberapa manfaat yang didapatkan anak-anak saat mendengar dongeng yang dibacakan atau diceritakan yang dikutip dari Kompas.com (Harususilo, 2018) adalah sebagai berikut:

\section{Perkembangan kognitif}

Untuk dapat memperluas pengenalan objek seorang anak, pada saat mendongeng, gunakan alat peraga misalnya buku bergambar. Dengan begitu, anak bisa melihat bentuk dari tokoh yang diceritakan dalam dongeng. Selain itu, dongeng juga dapat menambah wawasan. Melalui kisah- kisah dongeng, anak mendapatkan berbagai informasi. Anak juga dapat mempelajari sebab akibat serta belajar menganalisa. Melalui dongeng juga, pemikiran anak 
menjadi lebih baik, lebih kritis dan cerdas. Anak juga bisa memahami hal mana yang perlu ditiru dan tidak boleh.

\section{Perkembangan sosial dan emosional}

Dari kegiatan mendongeng, kita bisa menyelipkan ajaran normanorma seperti sosial, agama dan sopan santun. Tidak hanya teori, tapi ajarakan secara langsung bagaimana melakukannya. "Anak-anak cenderung mempunyai kesulitan dalam mempelajari nilai- nilai moral dalam kehidupan. Dengan dongeng anak-anak maka kita bisa memberikan contoh melalui tokoh dalam cerita yang kita dongengkan," jelasnya seperti dikutip dari laman Sahabat Keluarga Kementerian Pendidikan dan Kebudayaan.

\section{Memperat ikatan anak dan orang tua}

Kesibukan orang tua kerap kali membuat komunikasi anak dan orang tua kurang intensif. Dengan mendongeng, orang tua berdekatan secara intim, komunikasi efektif pun berjalan dengan baik.

\section{Mengembangkan daya imajinasi}

Dunia anak adalah dunia imajinasi. Anak memiliki dunia sendiri dan tak jarang mereka berbicara dengan teman khayalannya. Dengan daya imajinasi yang masih sangat bagus ini, maka orang tua harus bisa mengarahkannya ke arah yang positif dan tetap terkontrol. Anak yang kurang imajinasi bisa berakibat pada pergaulan yang kurang, sulit bersosialisasi atau beradaptasi dengan lingkungan yang baru.

\section{Meningkatkan keterampilan berbahasa}

Dongeng merupakan stimulasi dini yang mampu merangsang keterampilan berbahasa pada anak-anak.

Kisah-kisah dongeng yang mengandung cerita positif tentang perilaku membuat anakanak menjadi lebih mudah dalam menyerap tutur kata yang sopan.

Menurut Monica, dari segi perkembangan bahasa, anak yang sering mendengarkan orang tuanya mendongeng maka perkembangan linguistiknya lebih meningkat dibandingkan anak yang tidak pernah didongengkan.

\section{Membangkitkan minat baca \\ Dengan memberikan cerita dongeng pada anak-anak, mereka akan tertarik dan penasaran untuk mencari tahu. Inilah dimana keingian untuk membaca semakin meningkat.}

Pernyataan-pernyataan tersebut menggambarkan bahwa begitu pentingnya dongeng bagi anak-anak. Melalui dongeng, nilainilai budaya dapat diwariskan. Akan tetapi, masih terdapat anak-anak usia sekolah dasar yang sama sekali tidak pernah mendengar atau dibacakan dongeng baik oleh orang tua maupun guru. Hal ini tentu sangat memprihatinkan mengingat begitu banyaknya hal positif yang diperoleh melalui kegiatan mendongeng. Anakanak usia sekolah dasar bahkan belum pernah mendengar istilah "dongeng". Hal ini ditemui pada anak-anak usia sekolah dasar di KBG St. Faustina Ros 1D Kelurahan Golo Dukal. Pada pertemuan pertama, dengan menggunakan metode tanya jawab, tim PkM mencoba menggali pengetahuan awal anak-anak SEKAMI terkait dongeng lokal. Dari hasil tanya jawab diketahui, sebagian besar anak tidak mengetahui dongengdongeng lokal manggarai. Hal ini berbeda ketika tim PkM bertanya tentang dongeng-dongeng yang pernah mereka baca atau dengar. Hampir semua anak menjawab bahwa dongeng yang pernah mereka dengar dan baca yaitu dongengdongeng nasional, seperti Timun Mas, Kancil dan Buaya, dan sebagainya serta dongengdogeng luar negeri, seperti Snowball, putri salju, dan sebagainya.

Berdasarkan masalah yang ditemui 
tersebut, ditawarkan satu solusi yakni diadakannya kegiatan mendongeng sebagai wujud penanaman kearifan lokal daerah Manggarai. Melalui kegiatan ini, anak-anak usia sekolah dasar dikenalka dengan berbagai kearifan lokal daerah Manggarai.

Berdasarkan berbagai penjelasan pada latar belakang, kegiatan PkM ini tentu memiliki tujuan yang baik. Beberapa tujuan tersebut adalah sebagai berikut.

a. Memperkenalkan berbagai kearifan lokal daerah Manggarai kepada anak-anak usia sekolah dasar.

b. Menumbuhkan rasa cinta pada berbagai kearifan lokal daerah Manggarai.

c. Menumbuhkan dan mengembangkan mental dan kemampuan anak-anak untuk berbicara di depan teman-teman lainnya.

Luaran yang akan dihasilkan melalui kegiatan mendongeng ini adalah sebagai berikut.

a. Cerita rakyat asli Manggarai kembali populer di kalangan anak.

b. Terbentuknya karakter cinta budaya dalam diri anak.

c. Terbentuknya karakter anak-anak yang memiliki minat baca, daya imajinasi, dan tingkat kepercayaan diri yang tinggi.

d. Anak dapat tumbuh dan berkembang sesuai dengan umurnya.

e. Terbentuknya komunitas pecinta keilmuan lokal.

\section{METODE}

Kegiatan Pengabdian kepada Masyarakat $(\mathrm{PkM})$ ini diberikan kepada anak-anak Serikat Kerasulan Anak Misioner (SEKAMI). SEKAMI adalah sebuah wadah berhimpun Anak-Remaja Katolik di seluruh dunia untuk membangun iman dalam Yesus Kristus. Panggilan untuk menjadi Misionaris adalah panggilan setiap umat kristen. Semangat Misioner adalah semangat untuk mewartakan kabar gembira kepada semua bangsa. Panggilan menjadi Misioner dapat dipupuk mulai dari usia dini. Maka Gereja Katolik mengajak anak dan remaja untuk bergabung dan masuk dalam sebuah serikat yang mengusung Motto "Children Helping Children (Anak Menolong Anak) dan Misinya Doa, Derma, Kurban, Kesaksian. Anak-anak SEKAMI yang menjadi kelompok sasar kegiatan PkM ini adalah anak-anak SEKAMI di Paroki St. Nikolaus Golodukal yang berusia 7-10 tahun (2$5 \mathrm{SD})$.

Kegiatan ini menggunakan beberapa metode. Pertama, metode ceramah dan tanya jawab. Kedua, metode pendampingan dan pelatihan, dan ketiga metode unjuk kerja melalui lomba mendongeng.

Kegiatan ini dilaksanakan selama 3 bulan, yaitu pada Maret-Mei 2019, di Paroki St. Nikolaus Golodukal, yang diikuti oleh ... orang anak yang tergabung dalam SEKAMI. Pada saat pelaksanaan kegiatan, peserta dengan antusias mengikuti arahan dari pelaksana PkM yang merupakan pemateri dalam kegiatan tersebut. Pelaksana PkM memberikan materi sesuai dengan karakteristik anak SEKAMI. Setelah penyampaian materi, pelaksana $\mathrm{PkM}$ kemudian mendemonstrasikan mendongeng. Setelah demonstrasi, melalui metode unjuk kerja, anakanak SEKAMI mempraktikkan Mendongeng melalui perlombaan yang diadakan di aula Paroki St. Nikolaus Golodukal.

Tahapan kegiatan ini dibagi berdasarkan jenis kegiatan. Pertama, ceramah dan tanya jawab yang dipakai dalam kegiatan pengenalan tentang dongeng dengan kelompok sasar anakanak Serikat Kerasulan Anak Misioner atau yang sering disebut SEKAMI di Paroki St. Nikolaus Golodukal. Kegiatan ini bertujuan untuk menggali pengetahuan awal anak tentang dongeng yang mereka kenal dan pengalaman mereka tentang mendongeng.

Kedua, pendampingan dan pelatihan untuk mengembangkan kemampuan anak-anak SEKAMI dalam mengenal dongeng dan mendongeng. Kegiatan ini bertujuan untuk meningkatkan kemampuan anak-anak SEKAMI dalam mengenal lebih banyak dongeng dan cara mendongeng yang baik.

Ketiga, unjuk kerja untuk melihat kemampuan anak dalam mendongeng. Kegiatan ini bertujuan untuk melihat sejauhmana kemampuan anak dalam membawakan sebuah dongeng di hadapan teman-temannya.

Tahapan kegiatan PkM dimulai dari persiapan, pelaksanaan, dan diakhiri evaluasi. Tahap perencanaan, metode yang digunakan berupa wawancara. Wawancara digunakan untuk mendapatkan informasi dari mitra tekait kegiatan SEKAMI. Beberapa hal yang dilakukan pada tahap perencanaan, yaitu: (1) koordinasi tim PkM, (2) tim menghubungi mitra (pembina SEKAMI dan Pastor Paroki), (3) penentuan jadwal kegiatan (tim PkM bersama mitra), dan (4) mempersiapkan buku cerita rakyat Manggarai.

Tahap pelaksanaan metode yang digunakan berupa ceramah dan tanya jawab. 
Ceramah digunakan untuk mengenalkan dongeng pada anak SEKAMI Paroki St. Nikolaus Golodukal. Tanya jawab bertujuan menggali pengetahuan awal anak-anak tentang dongeng yang mereka kenal dan kegiatan mendongeng yang pernah dilakukan orang terdekat atau oleh anak sendiri. Selain itu, metode lain yang digunakan berupa pendampingan dan pelatihan bagi anak-anak SEKAMI. Kegiatan ini bertujuan untuk meningkatkan kemampuan anak-anak SEKAMI dalam mengenal lebih banyak dongeng dan bagaimana cara mendongeng yang baik dan menarik. Beberapa hal yang dilakukan pada tahap pelaksanaan, yaitu: (1) tim menggali dan mendata kembali cerita-cerita rakyat Manggarai, (2) pendekatan antara mitra dan Tim PkM (anakanak SEKAMI dan pendamping SEKAMI), (3) tim PkM melakukan sosialisasi terkait kegiatan yang dilakukan kepada anak-anak SEKAMI, (4) tim PkM menyampaikan materi tentang dongeng dan mendongeng kepada anak-anak SEKAMI, (5) tim PkM melakukan kegiatan mendongeng, kemudian meminta anak-anak untuk menjawab beberapa pertanyaan berkaitan dengan isi dongeng yang diceritakan, (6) tim PkM melakukan pendampingan dan latihan bagi anakanak untuk mendongeng di depan teman-teman, (7) memberi tugas kepada anak-anak SEKAMI untuk menanyakan dongeng (cerita rakyat) Manggarai pada orang tua atau keluarga mereka, (8) mengadakan lomba mendongeng dalam kelompok- kelompok usia (3 SD, $4 \mathrm{SD}$, dan 5 SD), dan (9) tim menentukan pemenang lomba dari setiap kategori usia dan membagi hadiah bagi para peserta lomba yang meraih juara 1,2 , dan 3 .

Tahap akhir berupa evaluasi dilakukan evaluasi mingguan dan evaluasi akhir. Evaluasi mingguan dilakukan untuk melihat efektivitas dan efisiensi kegiatan yang dilakuakan setiap minggu. Sementara itu, evaluasi akhir dilakukan untuk melihat ketercapaian tujuan dan target luaran dari program PkM. Hal ini dilakukan dengan melihat proses anak melakukan kegiatan mendongeng dan hasil dari lomba mendongeng tersebut.

\section{RENCANA TINDAK LANJUT KEGIATAN}

Berdasarkan hasil evaluasi kegiatan PkM berupa mendongeng bagi anak SEKAMI di Paroki St. Nikolus Golodukal, maka rancangan tindak lanjut dari kegiatan mendongeng, berupa: (1) membentuk komunitas pencinta dongeng, (2) menulis dongeng berdasarkan imajinasi anak, dan
(3) mengadakan lomba menulis dongeng bagi anak usia 7-10 tahun.

Pembentukan komunitas pencinta dongeng dimulai dari anak-anak SEKAMI di Paroki St. Nikolaus Golodukal yang tergabung dalam kegiatan PkM mendongeng yang dilakukan oleh tim PkM dosen STKIP St. Paulus Ruteng. Selanjutnya, bisa mengajak anak-anak SEKAMI di Paroki-paroki lain, baik di kota Ruteng, maupun di luar kota Ruteng.

Selain membentuk komunitas pencinta dongeng, tindak lanjut dari kegiatan ini berupa membangkitkan minat anak melalui PkM berikutnya untuk menulis dongeng sesuai dengan imajinasi mereka. Dunia anak merupakan dunia penuh imajinasi. Oleh karena itu, imajinasi tersebut akan lebih bermanfaat apabila disalurkan dalam bentuk menulis dongeng anak.

Terakhir, rencana tindak lanjut dari PkM adalah mengadakan lomba menulis dongeng. Diadakannya lomba akan membuat anak tertantang untuk menghasilkan dongeng yang baik dan menuangkan imajinasi mereka sekreatif mungkin.

\section{PELAKSANAAN KEGIATAN}

Dalam pelaksanaannya, kegiatan ini melewati beberapa tahap. Tahap-tahap tersebut terdiri dari tahap awal, tahap pelaksanaan dan tahap akhir kegiatan.

1. Tahap Awal

Sebelum kegiatan berlangsung, terdapat beberapa langkah sebagai persiapan pelaksanaan kegiatan antara lain sebagai berikut.

a. Rancangan kegiatan yang akan dilaksanakan

Pada tahap ini, tim menentukan beberapa hal terkait waktu bertemu mitra dan agenda yang akan dibahas bersama mitra.

b. Diskusi dengan mitra

Diskusi tim dengan mitra dilkukan pada tamggal 17 Februari 2019. Diskusi ini dilaksanakan di gereja Paroki St. Nikolaus Kelurahan Golodukal, Kecamatan Langke Rembong, Kabupaten Manggarai. Kegiatan diskusi bersama mitra berjalan baik. Ada beberapa hal yang dibahas dan disepakati dalam kegiatan ini, di antaranya adalah jadwal kegiatan, bentuk kegiatan, dan tujuan kegiatan. Berdasarkan hasil diskusi tersebut, ditentukan bahwa kegiatan dilakukan sebanyak 5 kali. 
Pertemuan pertama, perkenalan. Pertemuan kedua sampai keempat pelaksanaan inti kegiatan dan pertemuan kelima adalah penutup sekaligus membagikan penghargaan kepada anakanak SEKAMI Paroki St. Nikolaus Golodukal.

2. Tahap Pelaksanaan Kegiatan

a. Pengenalan kegiatan kepada anggota SEKAMI Paroki St. Nikolaus Golodukal Sebelum memulai kegiatan mendongeng, tim Pengabdian kepada Masyarakat memperkenalkan diri dan kegiatan yang akan dilakukan. Pada tahap ini, tujuan utama tim adalah terbentuknya keakraban antara anak-anak SEKAMI dengan tim PkM, sehingga sebaliknya, anak-anak SEKAMI juga memperkenalkan diri kepada tim. Selain itu, pada tahap ini diisi dengan begitu banyak permainan serta nyanyi-nyanyian yang dapat membentuk keakraban dan rasa persaudaraan. Hal ini dilakukan pada pertemuan pertama.

b. Kegiatan mendongeng

Selanjutnya, pertemuan berikutnya diisi oleh kegiatan mendongeng. Pada tahap ini terdapat beberapa hal yang dilakukan seperti;

$\checkmark \begin{array}{rr}\text { Menjelaskan konsep dasar } \\ \text { terkait dongeng } \\ & \text { Hal ini dilakukan agar anak-anak } \\ & \text { memahami makna dari dongeng. } \\ \checkmark & \text { Menjelaskan } \\ & \text { mempelajari dongeng terutama } \\ \text { dongeng- dongeng orang } & \text { manggarai }\end{array}$

Hal ini bertujuan agar anak-anak semakin mencintai dongeng dan melestarikan budaya Manggarai melalui kegiatan mendongeng. Selain itu, anak-anak juga dapat berimajinasi dan meningkatkan keterampilan berbahasa.

$\checkmark$ Menjelaskan dan memperagakan cara mendongeng yang baik dan benar seperti memperhatikan lafal, intonasi, ekspresi, volume suara, dan sikap saat mendongeng

Hal ini bertujuan agar anak-anak mampu berdongeng dengan baik serta menarik perhatian para pendengar, sehingga pendengar dapat memahami pesan dari dongeng tersebut.

$\checkmark \quad$ Mencontohkan cara mendongeng Tujuan dari kegiatan ini adalah agar anak-anak dapat medongeng sesuai dengan isi dari dongeng dan berekspresi dengan baik serta memperhatikan intonasi, pelafalan, dan volume suara.

Setelah beberapa hal tersebut dijelaskan tim, selanjutnya kesempatan mendongeng diberikan kepada anak-anak SEKAMI. Tim menugaskan anak-anak SEKAMI untuk mencari tahu dongeng asli orang Manggarai kepada orang tua mereka masing-masing. Berdasarkan tugas tersebut, pada pertemuan berikutnya, anak-anak SEKAMI mendongeng di depan tim dan temantemannya. Dalam pelaksanaanya, anakanak terlihat semangat dan memiliki antusias yang tinggi. Pada saat temannya mendongeng, anak-anak yang lain mendengar dengan penuh kosentrasi. Hal ini dibuktikan ketika tim menanyakan beberapa hal terkait isi dongeng, mereka berlomba-lomba mengacungkan tangan untuk menjawab setiap pertanyaan yang diberikan tim. Kegiatan ini dilakukan selama 3 kali pertemuan. Akan tetapi, terdapat beberapa anak yang belum memiliki keberanian untuk mendongeng di depan teman-temannya. Pada umumnya beberapa anak yang tidak memiliki keberanian adalah laki-laki.

c. Kegiatan Lomba Mendongeng

Lomba mendongeng dilakukan dalam tiga tahap, yaitu pertama kelompok anak kelas III SD; kedua, kelompok anak kelas IV SD; dan ketiga, kelompok anak kelas V SD. Dari tiga kelompok tersebut, ada 22 anak yang mendaftarkan diri sebagai peserta lomba, yaitu 3 orang kelas III, 12 orang kelas IV, dan 7 orang kelas V. Akan tetapi, tidak semua anak yang telah mendaftar hadir pada saat perlombaan. Dari 22 anak, hanya 12 anak yang hadir, yaitu 2 dari kelas III, 4 dari kelas IV, dan 6 dari kelas V. Pada saat perlombaan berlangsung, tim selaku juri menilai peserta yang sedang berdongeng. Ada beberapa aspek yang dinilai juri, di antaranya adalah intonasi, pelafalan, ekspresi, dan volume suara. 
Berdasarkan penilaian juri, ditentukan peserta yang meraih juara I, II, dan III dari masing-masing kelompok. Akan tetapi, untuk kelompok kelas III, juri hanya menentukan peserta yang meraih juara I dan II karena dari kelompok tersebut, hanya 2 peserta yang mengikuti lomba mendongeng. Anak-anak yang meraih juara I, II, dan III diberikan hadiah.

\section{Tahap Akhir}

Pada tahap akhir kegiatan, tim memberikan piagam penghargaan baik kepada anggota lomba, yang menjuarai lomba, maupun pembina SEKAMI. Hal ini dilakukan pada pertemuan ke lima (pertemuan terakhir)

\section{HASIL DAN PEMBAHASAN}

\section{Jumlah Dongeng yang Dikumpulkan}

Jumlah dongeng yang dikumpulkan adalah 18 dongeng, yakni 6 dongeng pada tahap kegiatan mendongeng dan 12 dongeng pada saat lomba mendongeng. Dari 18 dongeng yang dikumpulkan tersebut, ada 3 dongeng yang menggunakan bahasa Manggarai, sedangkan 15 dongeng lainnya menggunakan bahasa Indonesia.

\section{Jenis-Jenis Dongeng Pilihan Anak}

Jenis dongeng yang didongengkan adalah fable dan legenda. Fable merupakan cerita tentang kehidupan binatang, seperti kisah kerbau dan semut, kera dan katak, dan lain-lain. Legenda merupakan cerita yang mengisahkan tentang asal-usul terbentuknya suatu tempat, seperti kisah terjadinya ulumbu, terjadinya Rana Poja, terjadinya Rana Mese, dan lain sebagainya.

\section{Jumlah Anak yang Mengikuti Kegiatan}

Jumlah anak yang ikut SEKAMI adalah 45 orang. Dari 45 anak tersebut, yang mendaftarkan diri untuk ikut lomba mendongeng adalah 22 anak. Akan tetapi, pada saat pelaksanaan lomba mendongeng, hanya 12 anak yang bersedia mengikuti lomba, sedangkan 10 anak lainnya tidak datang.

\section{Minat Anak Terhadap Dongeng}

Berdasarkan hasil kegiatan pengabdian yang telah dilaksanakan, anak- anak SEKAMI yang menjadi anggota resmi memiliki minat yang tinggi terhadap dongeng anak. Hal ini terlihat pada antusias dan kehadiran anak saat kegiatan berlangsung. Walaupun tidak semua anak mengambil bagian menjadi peserta lomba, tetapi kehadiran anak menunjukkan bahwa mereka memiliki minat yang tinggi hanya saja belum mengumpulkan keberanian untuk berdongeng di depan teman-temannya.

\section{Sekilas Deskripsi mengenai Kemampuan Anak dalam Mendongeng}

Seperti yang telah dijelaskan sebelumnya bahwa dari 45 orang anak yang menjadi anggota SEKAMI, terdapat 22 orang anak yang berminat mengikuti dan menjadi peserta lomba. Dari 22 orang anak yang mengikuti lomba tersebut terdapat hanya 10 orang yang mengikuti lomba. Adapun kemampuan anak-anak bervariasi. Adapun beberapa aspek yang dinilai saat anak mendongeng adalah alur cerita, penggunaan bahasa saat menceriterakan dongeng, intonasi, dan ekspresi anak.

a) Alur cerita

Alur merupakan struktur rangkaian kejadian dalam cerita yang disusun secara kronilogis. Dalam pelaksanaan mendongeng, tidak semua anak mampu menceritakan dongeng sesuai alur dari awal sampai akhir. Sebagian besar anak lupa dengan jalan cerita dongeng. Hal inimembuat anak menjadi malu dan memutuskan untuk berhenti berceritera. Hal ini terjadi pada pertemuan awal. Akan tetapi, seiring berjalannya kegiatan, anak-anak berusaha untuk bisa menghafal dongeng yang dipilih. Hal tersebut pun tidak sia-sia. Pada pelaksanaan lomba mendongeng, semua peserta lomba mampu mendongeng dengan baik dengan alur yang lengkap.

b) Penggunaan bahasa saat menceriterakan

Penggunaan bahasa saat mendongeng menjadi salah satu aspek yang dinilai karena peserta SEKAMI berada pada lingkungan yang memiliki bahasa yang kompleks yaitu bahasa daerah dan bahasa Indonesia. Adapun pada pelaksanaan mendongeng terdapat anak-anak yang menggunakan baik bahasa Indonesia maupun bahasa daerah.

c) Ekspresi

Ekspresi menjadi salah satu aspek yang dinilai saat mendongeng. Ekspresi merupakan mimik wajah, ucapan, vokal, penjiwaan, gerak, akting, dan bloking. Mendongeng membutuhkan ekspresi. Dengan ekspresi, pendongeng dapat mengutarakan maksudnya. Dalam pelaksanaan kegiatan mendongeng, anak-anak memiliki kemampuan berekspresi yang sangat baik. 


\section{Aktivitas-aktivitas SEKAMI yang Biasa Dilakukan}

Dalam kelompok SEKAMI, kegiatan yang dilakukan bervariasi. Adapun beberapa kegiatan-kegiatan yang biasa dilakukan kelompok SEKAMI antara lain sebagai berikut.

a) Gerak dan lagu

Gerak dan lagu menjadi aktivitas utama anak-anak SEKAMI. Hal ini hampir dilakukan setiap setelah misa kedua. Gerak dan lagu biasa dipimpin anggota SEKAMI senior atau biasa disebut kakak pembina SEKAMI.

b) Sharing kitab suci

Selain gerak dan lagu, kegiatan lain yang dilakukan anak-anak SEKAMI adalah kegiatan sharing kitab suci. Kegiatan ini biasa dilakukan sekali seminggu dan dipimpin oleh senior dan seorang suster pembina. Sharing kitab suci memberikan mabnfaat yang baik untuk anakanak karena dapat menumbuhkan minat anak dalam berbagi dan bersosialisasi dengan temantemannya.

c) Ziarah saat bulan Maria

Ziarah saat bulan Maria dilakukan setiap bulan Maria yakni Oktober dan Mei. Hal ini dilakukan dengan tujuan membentuk pribadi dan tabiat anak untuk membiasakan diri berziarah sebagai salah salah satu kegiatan penting agama Katolik.

d) Kelompok tari dan teater untuk kegiatan pentas di gereja

Terdapat pula kelompok tari dan teater. Kelompok ini dibentuk untuk mengisi berbagai acara-acara pentas gereja. Misalnya, perpisahan pastor paroki, hari ulang tahun gereja, dan sebagainya.

e) Bakti sosial seperti bersih2 gereja dan dekorasi gereja

Anak-anak SEKAMI juga memiliki jadwal khusus untuk bersih-bersih sekitar gereja. Selain membersihkan gereja dan sekitarnya, anak-anak SEKAMI dilatih untuk mendekorasi altar dan bagian-bagian tertentu di dalam gereja.

f) Putra-putri altar

Anak-anak SEKAMI memiliki kelompok putra-putri altar. Hal ini bertujuan agar anak-anak dilatih untuk mendekatkan diri pada Tuhan dan selalu memprioritaskan berbagai kepentingan di Gereja.

\section{Dampak Positif Kegiatan}

Dengan adanya kegiatan ini di antaranya, anak menjadi tertarik untuk mengetahui dongeng lokal ditandai anak antusias bertanya kepada orang tua dan kerabat terdekat serta besemangat mengikuti lomba mendongeng yang diadakan oleh tim PkM. Selain itu, anak-anak meminta kegiatan ini untuk tetap dilanjutkan.

\section{KESIMPULAN}

Mendongeng merupakan salah satu bentuk tradisi lisan sebagai sarana komunikasi dan merekam peristiwa-peristiwa kehidupan masa lampau. Dongeng dapat dijadikan sebagai wadah untuk melestarikan kearifan lokal, khususnya daerah Manggarai. Cerita dari dongeng dapat dipetik manfaatnya, terutama dongeng-dongeng yang mengandung pesan moral. Oleh karena itu, pendongeng harus pandai memilih dongeng yang sesuai dengan usia anak serta mengandung nilai pendidikan yang bermanfaat untuk anak.

Kegiatan mendongeng pada anak usia SD di SEKAMI paroki St. Nikolaus Golodukal mendapat respon yang sangat baik dari anakanak. Dengan kegiatan ini, anak-anak mengetahui berbagai cerita rakyat Manggarai, baik yang didongengkan oleh tim, temantemannya, maupun yang ditanyakan pada orang tua mereka. Selain itu, mereka juga dapat berdongeng dengan baik. Hal ini terbukti ketika berdongeng di depan teman-teman, mereka sangat bersemangat dan memahami pesan dari dongeng tersebut serta memperhatikan intonasi, pelafalan, volume suara dan ekspresi ketika berdongeng.

Kegiatan mendongeng sebagai program tepat guna dalam melestarikan kearifan lokal daerah Manggarai tidak hanya dapat mewadahi anak usia SD di Paroki St. Nikolaus Golodukal, akan tetapi dapat dikembangkan untuk semua anak SD di daerah Manggarai. Oleh karena itu, diharapkan kedepannya program ini dapat dikembangkan dengan integrasi peran dari pihakpihak terkait, seperti pihak sekolah, pemerintah, para akademisi, Lembaga Swadaya Masyarakat (LSM) yang bergerak dalam bidang pendidikan budaya, dan lain sebagainya.

\section{DAFTAR RUJUKAN}

Ayat, Rohadi. 1986. Kepribadian Budaya Bangsa (Local Genius). Jakarta : Pustaka Jaya.

Barung,Kanis. 2010. Pembelajaran Cerita

Lokal Manggarai Timur. Ruteng: CV Graffiko.

Harususilo, Yohanes Enggar . 2018. Manfaat Mendongeng untuk Anak. Kompas.com https://edukasi.kompas.com/read/2018/0 
6/17/21492131/6- manfaat-

mendongeng-untuk-anak

DE. 2017. Lestarikan

Kearifan Lokal Lewat

Dongeng. $\quad$ https://www.kabar-

banten.com/lestarikan-kearifan-lokal-

lewat- dongeng/ (14 November 2017).

Wibowo, A. dkk.,. Pendidkan Karakter Berbasis

kearifan Lokal di Sekolah. Yogyakarta :

Pustaka pelajar 